\title{
On a small collection of spiders (Aranei) from the Astrakhan Reserve (Russia)
}

\author{
О небомьшой комлекции пауков (Aranei) из Астраханского \\ заповедника (Россия)
}

\section{A.V. Ponomarev', V.V. Bastaev², D.A. Dubovikoff', V.Yu. Shmatko ${ }^{1}$ А.В. Пономарёв ${ }^{1}$, В.В. Бастаев ${ }^{2}$, А.А. Аубовиков ${ }^{2}$, В.Ю. Шматко ${ }^{1}$}

\footnotetext{
${ }^{1}$ Southern Scientific Centre of RAS, Chekhov Str., 41, Rostov-on-Don 344006 Russiap E-mail: ponomarev1952@mail.ru

${ }^{1}$ Южный научный центр РАН, пр. Чехова, 41, Ростов-на-Дону 344006 Россия.

${ }^{2}$ Department of Applied Ecology, Faculty of Biology, Saint Petersburg State University, $16^{\text {th }}$ line of Vasilievsky Island, 29, St. Petersburg 199178 Russiap

2 Кафедра прикладной экологии, Биологический факультет, Санкт-Петербургский государственный университет, 16-я линия Васильевского острова, 29, Санкт-Петербург 199178 Россия.
}

KEY WORDS: spiders, fauna, Astrakhan Reserve, new findings.

КЛЮЧЕВЫЕ СЛОВА: пауки, фауна, Астраханский заповедник, новые находки.

ABSTRACT. An annotated list of 89 spider species in 17 families found in the Damchik site of the Astrakhan Reserve (Russia) in 2017 is provided; of them 30 species are new to the fauna of Astrakhan Area, 57 species are first recorded from the Astrakhan Reserve; three species remain undetermined or determined provisionally: Haplodrassus sp., Poecilochroa cf. senilis, Heriaeus sp; 11 species are illustrated.

How to cite this article: Ponomarev A.V., Bastaev V.V., Dubovikoff D.A., Shmatko V.Yu. 2018. On a small collection of spiders (Aranei) from the Astrakhan Reserve (Russia) // Arthropoda Selecta. Vol.27. No.3. P.244-256. doi: 10.15298/arthsel. 27.3.09

РЕЗЮМЕ. Приводится аннотированный список 89 видов пауков из 17 семейств, обнаруженных на территории Дамчикского участка Астраханского заповедника (Россия) в 2017 году; из них 30 видов являются новыми для фауны Астраханской области, 57 видов впервые отмечаются в Астраханском заповеднике; не опредлены или определны предварительно 3 вида: Haplodrassus sp., Poecilochroa $\mathrm{cf}$. senilis, Heriaeus sp; 11 видов проиллюстрированы.

\section{Introduction}

The Astrakhan Biosphere Reserve is located in the lower reaches of the Volga delta, which belongs to the intrazonal delta area of the Caspian Region of the semi-desert zone, bordering the lacustrine province of the Caspian Region [Astrakhan Reserve, 1991]. The uniqueness of the Astrakhan Reserve is due to the fact that it covers significant areas of the largest delta in Europe and at the same time lies in the arid climatic zone. Against the background of reed thickets and willow forests, there are elements of steppe and desert landscapes: viz., sandy massifs, meadows of different degrees of moistening, salt-marshes, Tamarix thickets, areas of dry steppe and desert vegetation, etc. The diversity of microclimate and vegetation promotes the coexistence of various ecological and zoogeographical animal groups in such a small territory.

The spider fauna of the Astrakhan Reserve has been poorly studied yet. The first and to date the only list of spiders of the Reserve [Utochkin, 1971] contains 44 species only. Later [Ponomarev, 1981; Utochkin, 1985; Ponomarev et al., 2008], another 20 species were added to the list. Thus, to date a total of 64 spider species in 16 families has been recorded from the Reserve at hand.

Below, we present the results of a spider survey in the Astrakhan Reserve based on the materials collected by us in 2017 . The obtained data greatly expand our knowledge of its spider fauna.

\section{Material and methods}

The studied material was collected by V.V. Bastaev from the Damchik site of the Astrakhan Biosphere Reserve (Map 1) in the period from 26.06 to 3.07.2017. Different collecting methods, such as hand-collecting by means of forceps, aspirators and/or entomological nets, as well as pitfall traps and sifters, were used. A total of some 1500 spider specimens was collected, of which over 900 were adults. The material is shared between the collection of the St. Petersburg University and the personal collection of A.V. Ponomarev. Photographs were taken at the Southern Scientific Center of the Russian Academy of Sciences, by means of a microscope MICMED-6 using a SONY NEX-C3 16.2mp digital camera and Microphotoset (MFN-12). 


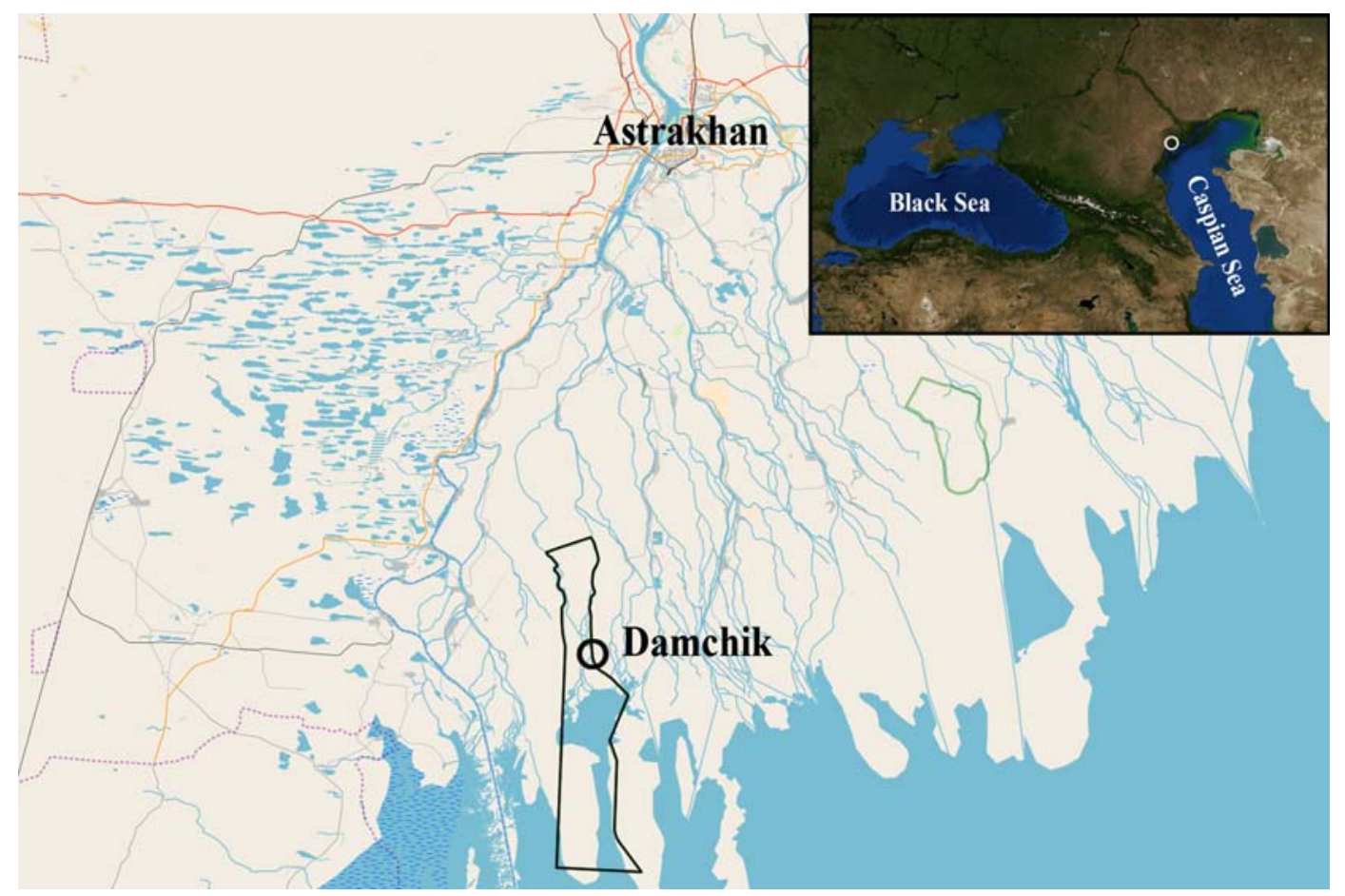

Map 1. Geographic location of the Damchik site of the Astrakhan Reserve.

Карта 1. Месторасположение Дамчикского участка Астраханского заповедника.

\section{Survey of species}

\section{ARANEIDAE}

Argiope lobata (Pallas, 1772)

MATERIAL. 1 i juv., saltmarsh with Bassia sedoides and Tamarix sp., 26.06-3.07.2017; 107 , forb-grass meadow, 28.06-3.07. 2017.

Hypsosinga heri (Hahn, 1831)

MATERIAL. 1을 edge of reeds (Phragmites australis), 3.07. 2017.

COMMENTS. A new species to the fauna of Astrakhan Area. In the Lower Volga region, it was recorded from Sarepta (now Volgograd Area) [Thorell, 1875].

Larinioides folium (Schrank, 1803)

RECORDS. Astrakhan Reserve [Utochkin, 1971: Araneus].

MATERIAL. $10^{\top}, 19$, boggy meadow with cattail (Typha angustifolia), 29.06.2017; $20^{\top} \sigma^{7}, 1+$, shore of ducts, 29.06.2017; 1 , reed thicket (Phragmites australis), 26.06-3.07.2017.

Larinioides ixobolus (Thorell, 1873)

RECORDS. Astrakhan Reserve [Utochkin, 1971: Araneus].

MATERIAL. $30^{7} 0^{7}, 1+$, on the Damchik cordon, 26.06-3.07. 2017.

Neoscona adianta (Walckenaer, 1802)

MATERIAL, $30^{7} \sigma^{7}$, saltmarsh with Bassia sedoides and Tamarix sp., 26.06-3.07.2017; $10^{7}$, dry wormwood-grass meadow, 27.06-3.07.2017; $60^{7} 0^{7}, 4$, 9 , salted dry meadow with camel-thorn (Alhagi pseudalhagi) and Tamarix sp., 27.06-3.07.2017; $20^{7} 0^{7}$, 2 우, tall grass meadow along willow stands (Salix spp.), 27.06-
3.07.2017; $20^{\top} \mathrm{O}^{7}, 1$, , reed-sedge meadow, 28.06.2017; $20^{\top} \mathrm{O}^{\top}$, forb-grass meadow, 28.06-3.07.2017; 1 , wet forb meadow in willow stands, 29.06-3.07.2017; $10^{7}$, sweeping over Tamarix sp., $26.06-3.07 .2017$

\section{CLUBIONIDAE}

Clubiona neglecta O. Pickard-Cambridge, 1862

MATERIAL. 107, cordon, indoor, 26.06-3.07.2017.

COMMENTS. A new species to the fauna of Astrakhan Area. Widely distributed in the Palearctic Region [WSC, 2018].

Clubiona pallidula (Clerck, 1758)

MATERIAL. 19 , boggy meadow with cattail (Typha angustifolia), 29.06.2017.

COMMENTS. A new species to the fauna of Astrakhan Area. Widely distributed in Europe [Nentwig et al., 2018].

Clubiona phragmitis C.L. Koch, 1843

RECORDS. Astrakhan Reserve [Utochkin, 1971].

MATERIAL. 19, boggy meadow with cattail (Typha angustifolia), 29.06.2017.

\section{DICTYNIDAE}

Argenna patula (Simon, 1874)

RECORDS. Astrakhan Reserve [Ponomarev et al., 2008]. MATERIAL. 1웅 reed meadow, 3.07.2017.

\section{GNAPHOSIDAE} 1872)

Aphantaulax trifasciata (O. Pickard-Cambridge,

MATERIAL. 107, dry wormwood-grass meadow, 27.06-3.07. 2017; 1 , reed-sedge meadow, 28.06.2017; $1 \sigma^{\top}, 1$, , salted forbgrass meadow, 2.07.2017. 


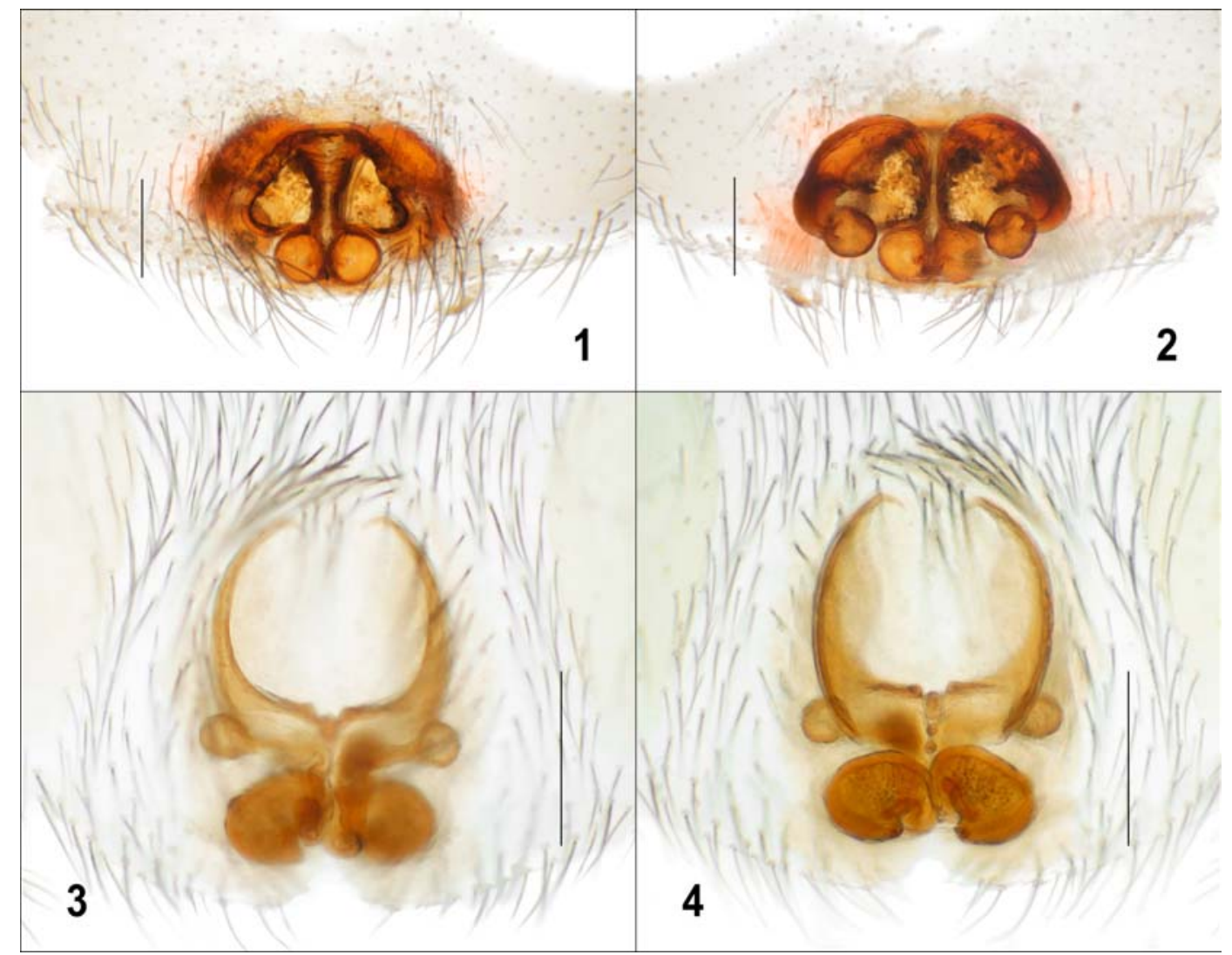

Figs 1-4. Epigynes of Berlandina nabozhenkoi $(1,2)$ and Cryptodrassus helvolus $(3,4): 1,3$ - ventral view; 2, 4 - dorsal view. Scale bars: Figs 1, 2-0.25 mm; Figs 3, $4-0.2 \mathrm{~mm}$.

Рис. 1-4. Эпигины Berlandina nabozhenkoi $(1,2)$ и Cryptodrassus helvolus $(3,4): 1,3$ - вид снизу; 2, 4 - вид сверху. Масштаб: рис. $1,2-0,25$ мм; рис. $3,4-0,2$ мм.

COMMENTS. A new species to the fauna of Astrakhan Area. In the Lower Volga region, it was recorded from the vicinity of Volgograd [Ponomarev, Khnykin, 2013].

Berlandina nabozhenkoi Ponomarev et Tsvetkov, 2006 Figs $1-2$.

Berlandina nabozhenkoi Ponomarev et Tsvetkov, 2006: 6, f. $1-2\left(\sigma^{7}\right)$. Berla
$\left(\mathrm{O}^{\top}+\right)$.

Berlandina nabozhenkoi: Ponomarev, 2008: 79-80, f. 1b, 2a-c

Berlandina nabozhenkoi: Marusik, Fomichev et Omelko, 2014: 210, f. 105-110 ( $\left.\sigma^{7}\right)$.

MATERIAL. $1+$, salted meadow with Tamarix sp., 26.06-3. 07.2017 .

COMMENTS. The species was described from the single male from Astrakhan Area, the vicinity of Ikryanoe Vil. [Ponomarev, Tsvetkov, 2006]. Later, it was found in Kalmykia, the vicinity of Ulan Khol [Ponomarev, 2008] and in islands and the coastline of Caspian Sea in northern Dagestan [Ponomarev, Abdurakhmanov, 2014]. As the description of the female was based on a single specimen [Ponomarev, 2008], with its epigyne being illustrated from the ventral view only, in the present paper we have provided additional drawings of the epigyne based on the studied specimen from the Astrakhan Reserve (Figs 1-2). Thus, all the findings of this species, including the current one, are confined to the north-west region of Caspian Sea.
Civizelotes caucasius (L. Koch, 1866)

MATERIAL. $20^{7} \sigma^{7}, 3$ 우, salted dry meadow with camel-thorn (Alhagi pseudalhagi) and Tamarix sp., 27.06-3.07.2017.

Cryptodrassus helvolus (O. Pickard-Cambridge, 1872) Map 2, Figs 3-4.

Melanophora helvola O. Pickard-Cambridge, 1872: 243, pl. 16, f. $23\left(\mathrm{O}^{7}\right)$.

Zelotes helvolus: Levy, 1998, 148, f. 120-122 ( $\left.\sigma^{7}\right)$.

Zelotes helvoloides: Levy, 1998, 150, f. 126-127 (ㅇ, misidentification).

Cryptodrassus helvolus: Chatzaki, Russell-Smith, 2017, 239, f. $1-6\left(\sigma^{\top}+\right)$.

Zelotes helvolus: Ponomarev et al., 2017, 111, f. 9-10 ( $\left.0^{7}\right)$.

MATERIAL. 390 , saltmarsh with Bassia sedoides and Tamarix sp., 26.06-3.07.2017.

COMMENTS. The structure of the epigyne of the studied females (Figs 3-4) undoubtedly indicates that they belong to $C$. helvolus. The species is known from Israel [O. Pickard-Cambridge, 1872; Levy, 1998], Cyprus [Chatzaki, Russell-Smith, 2017], Stavropol Territory (the shore of the Chogray reservoir) [Ponomarev et al., 2017] and now from the western part of the Volga Delta. The distance between the findings of this species in the Eastern Mediterranean and the North-Western Caspian region (Map 2) is about 1500 $\mathrm{km}$. Thus, the species range can be described as a disjunctive Eastern Mediterranean-Northern Caspian one. 


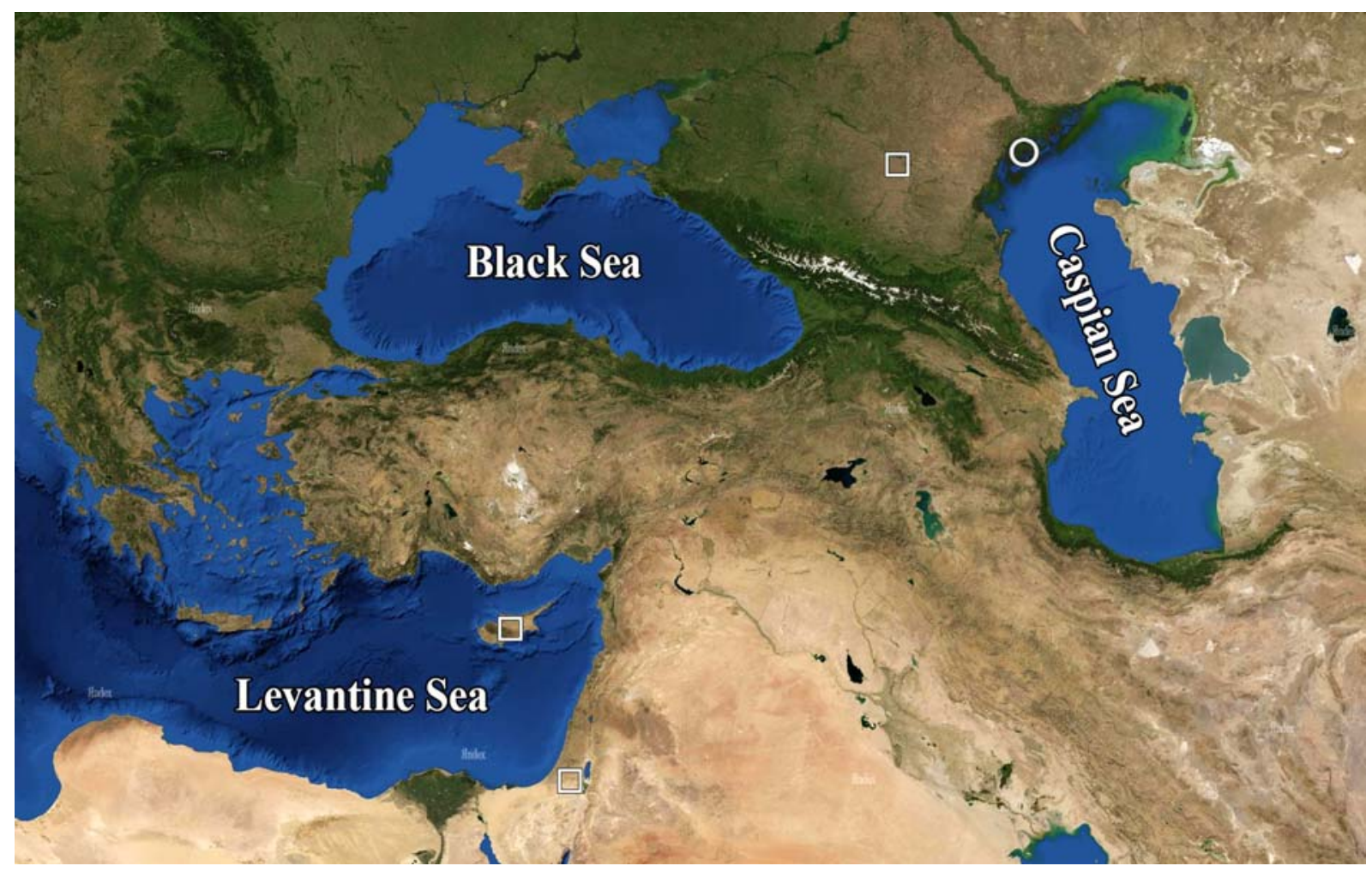

Map 2. Map of localities of Cryptodrassus helvolus: square - literature records; circle — new records.

Карта 2. Места находок Cryptodrassus helvolus: квадрат — литературные данные; круг — наши данные.

Drassodes caspius Ponomarev et Tsvetkov, 2006

RECORDS. Poldnevoe [Ponomarev, 1981: sub Drassodes pubescens, misidentification].

MATERIAL. $10^{7}$, salted dry meadow with camel-thorn (Alhagi pseudalhagi) and Tamarix sp., 27.06-3.07.2017.

Drassyllus lutetianus (L. Koch, 1866)

MATERIAL. $140^{7} \sigma^{\top}, 1$, , wet forb meadow in willow stands, 29.06-3.07.2017.

Drassyllus pusillus (C.L. Koch, 1833)

MATERIAL. 1엉 salted dry meadow with camel-thorn (Alhagi pseudalhagi) and Tamarix sp., 27.06-3.07.2017; 430 $0^{7}, 13$ 우, wet forb meadow in willow stands, 29.06-3.07.2017.

Gnaphosa leporina (L. Koch, 1866)

RECORDS. Poldnevoe [Ponomarev, 1981].

MATERIAL. $10^{7}, 1$, , saltmarsh with Bassia sedoides and Tamarix sp., 26.06-3.07.2017; $10^{7}$, salted dry meadow with camel-thorn (Alhagi pseudalhagi) and Tamarix sp., 27.06-3.07.2017; $10^{7}$, cordon, meadow, 26.06-3.07.2017. 1992

Gnaphosa saurica Ovtsharenko, Platnick et Song,

MATERIAL. $90^{7} \sigma^{7}, 2 \circ \circ$, saltmarsh with Bassia sedoides and Tamarix sp., 26.06-3.07.2017.

Haplodrassus dalmatensis (L. Koch, 1866)

MATERIAL. $1 \sigma^{7}$, saltmarsh with Bassia sedoides and Tamarix sp., 26.06-3.07.2017.

Haplodrassus minor (O. Pickard-Cambridge, 1879)

MATERIAL. $10^{7}$, wet forb meadow in willow stands, 29.063.07.2017.

\section{Haplodrassus sp.}

Fig. 5.

MATERIAL. 19 , wet forb meadow in willow stands, 29.06 3.07.2017; 1 우, cordon, meadow, 26.06-3.07.2017.

COMMENTS. Based on the epigynal structure (Fig. 5), the studied specimens is close to $H$. minor, but seems to belong to an undescribed species.

\section{Micaria bosmansi Kovblyuk et Nadolny, 2008}

$$
\text { Figs 6-7. }
$$
$\left(O^{7}+\right)$

Micaria bosmansi Kovblyuk et Nadolny, 2008: 224, f. 48-62

MATERIAL. 107 , cordon, meadow, 26.06-3.07.2017.

COMMENTS. Conformation of the male palp of the studied specimen (Figs 6-7) beyond doubts indicates that it belongs to $M$. bosmansi. A new species to the fauna of Astrakhan Area; described from the Crimea [Kovblyuk, Nadolny, 2008], later was recorded from Rostov and Volgograd Areas [Ponomarev, Dvadnenko, 2012; Ponomarev, Khnykin, 2013].

Micaria dives (Lucas, 1846)

MATERIAL. 1옹 salted dry meadow with camel-thorn (Alhagi pseudalhagi) and Tamarix sp., 27.06-3.07.2017.

COMMENTS. A new species to the fauna of Astrakhan Area. In the Lower Volga region, it was recorded from the vicinity of Volgograd [Ponomarev, Khnykin, 2013].

Micaria rossica Thorell, 1875

MATERIAL. $30^{7} \mathrm{O}^{7}$, salted dry meadow with camel-thorn $(\mathrm{Al}-$ hagi pseudalhagi) and Tamarix sp., 27.06-3.07.2017. 


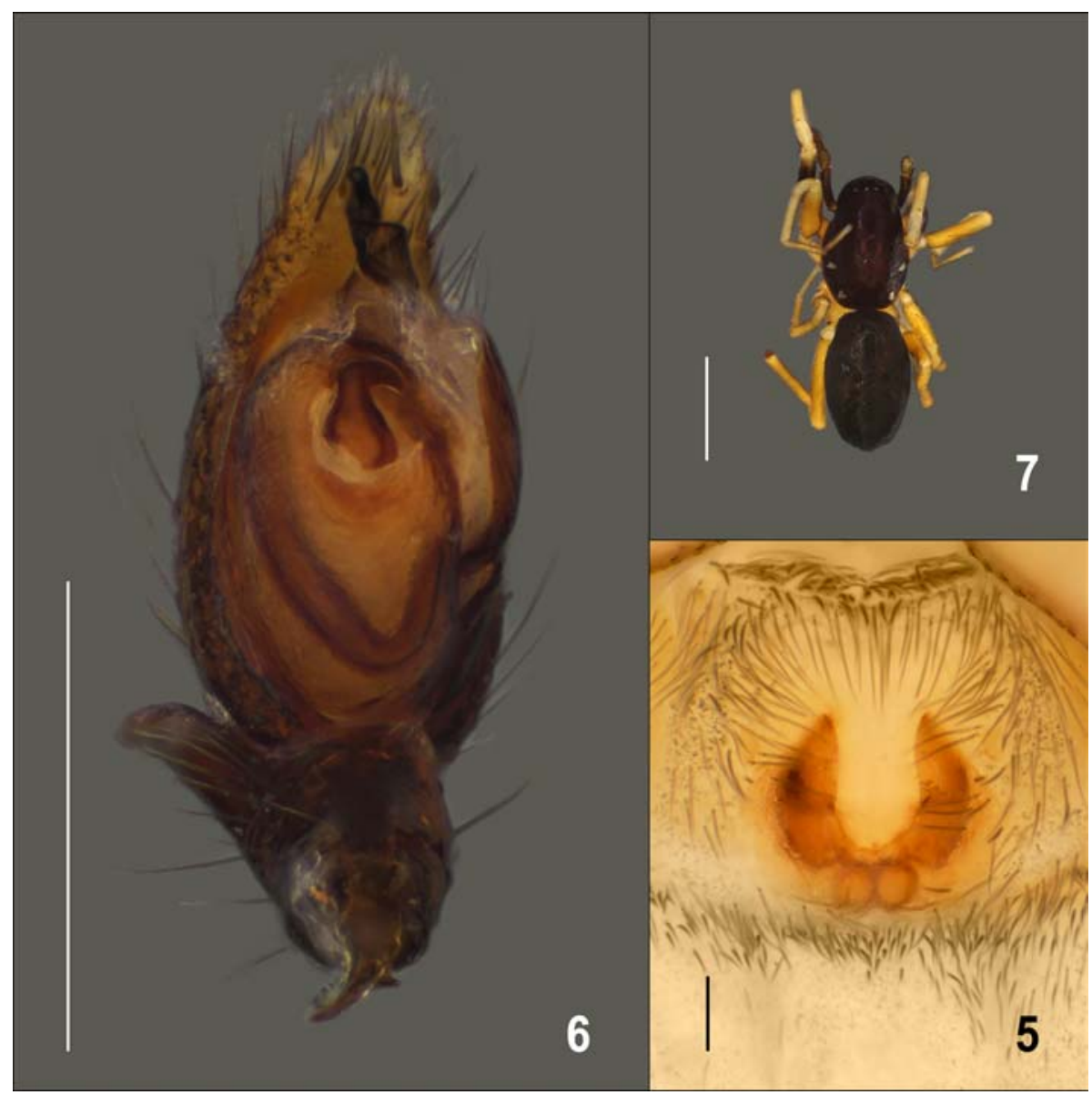

Figs 5-7. Copulatory organs (5, 6) and habitus (7) of Haplodrassus sp. (5) and Micaria bosmansi (6, 7): 5 - epigyne, ventral view; 6 male palp, ventral view; $7-$ male, dorsal view. Scale bars: fig. $5-0.2 \mathrm{~mm}$; fig. $6-0.25 \mathrm{~mm}$; fig. $7-1 \mathrm{~mm}$.

Рис. 5-7. Копулятивные органы $(5,6)$ и внешний вид (7) Haplodrassus sp. (5) и Micaria bosmansi $(6,7): 5$ - эпигина, вид снизу; 6 - пальпа самца, вид снизу; 7 - самец, вид сверху. Масштаб: рис. $5-0,2$ мм; рис. $6-0,25$ мм; рис. $7-1$ мм.

Poecilochroa cf. senilis (O. Pickard-Cambridge, 1872) Figs 8-9.

MATERIAL. 19, canal bank, 29.06.2017.

COMMENTS. Based on the conformtion of the epigyne (Figs 8-9), the studied specimen is close to P. senilis, which is widespread in the Mediterranean [Nentwig et al., 2018] and in southern regions of European Russia [Kovblyuk, Tuneva, 2008; Ponomarev et al., 2017]. However, the identification based on a single female leaves some doubts in its conspecificity with true $P$. senilis and requires a male for its verification.

Talanites fagei Spassky, 1938

MATERIAL. $10^{7}, 2+9$, saltmarsh with Bassia sedoides and Tamarix sp., 26.06-3.07.2017.

\section{Trachyzelotes cumensis (Ponomarev, 1979)}

Figs $10-11$.

Zelotes cumensis Ponomarev, 1979: 923, f. 8 ( + ).

Trachyzelotes cumensis: Ponomarev, Tsvetkov, 2004, 94, f. 11-12 (O'O).

MATERIAL. 290 , wet forb meadow in willow stands, 29.063.07.2017.
COMMENTS. A new species to the fauna of Astrakhan Area. Described form Kalmykia [Ponomarev, 1979], and then has been recorded from the shores of Black and Azov Seas, northern Dagestan (Russia) and Azerbaijan [Ponomarev, Tsvetkov, 2004; Mikhailov, 2013; Polchaninova, Prokopenko, 2013; Ponomarev et al., 2011, 2016, 2017; Ponomarev, 2017]. Due to insufficient knowledge of this species, figures of the epigyne (Figs 10-11) based on the female from the Astrakhan nature reserve has been provided.

Trachyzelotes malkini Platnick et Murphy, 1984

MATERIAL. $10^{7}, 1$, saltmarsh with Bassia sedoides and Tamarix sp., 26.06-3.07.2017; 4우, cordon, meadow, 26.06-3.07. 2017.

Zelotes mikhailovi Marusik in Eskov et Marusik, 1995 Figs 12-13.

Zelotes mikhailovi Marusik in Eskov et Marusik, 1995: 63, f 30, 34-35, 41 ( ( $^{7}+$ ).

Zelotes mikhailovi: Ponomarev, 2018: 4, f. 7-8 ( $\left.\sigma^{7}+\right)$.

MATERIAL. 390 , saltmarsh with Bassia sedoides and Tamarix sp., 26.06-3.07.2017.

COMMENTS. The conformation of the epigyne of the studied specimens (Figs 12-13) undoubtedly indicates that 


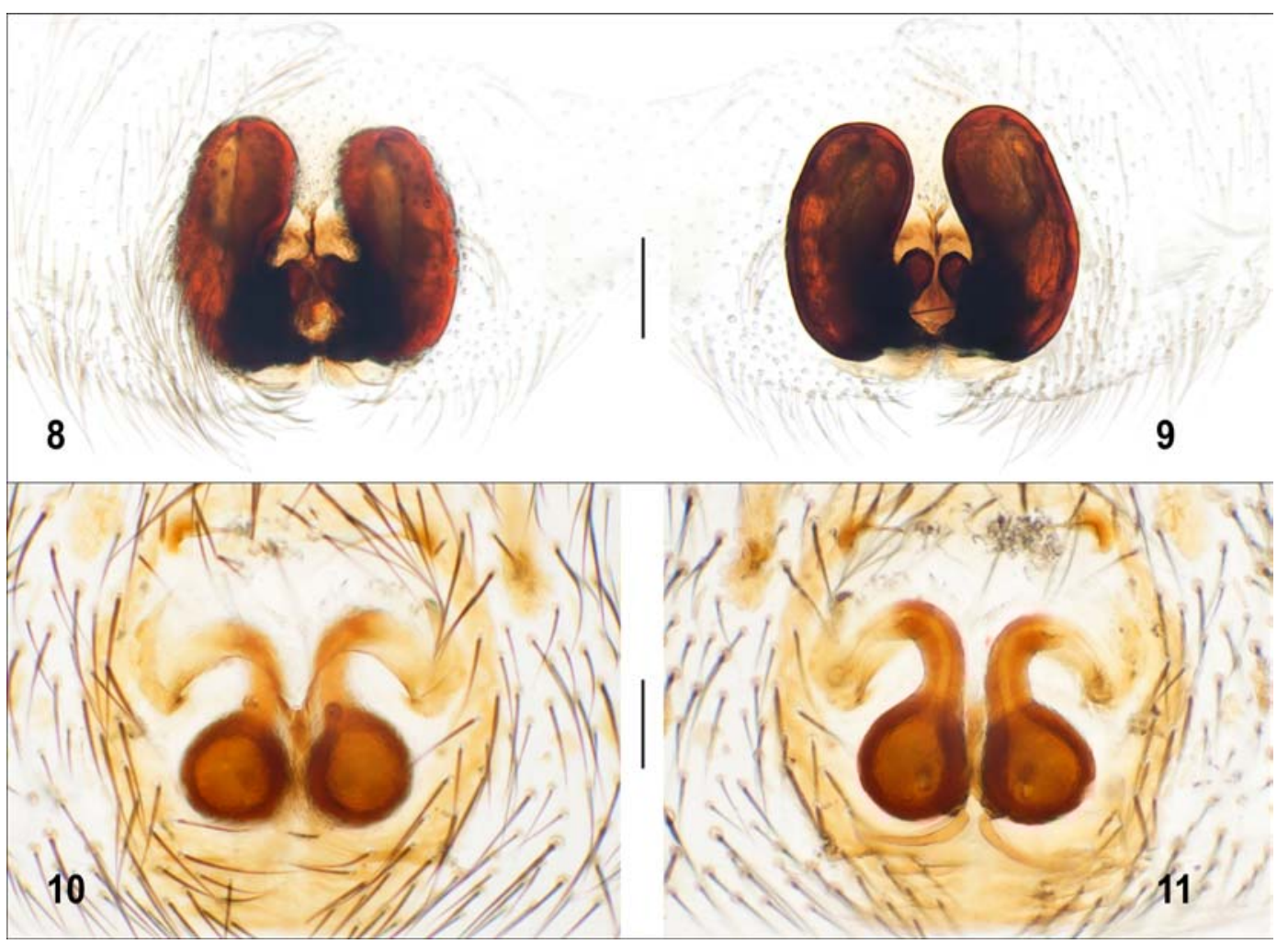

Figs 8-11. Epigynes of Poecilochroa cf. senilis $(8,9)$ and Thachyzelotes cumensis $(10,11): 8,10$ - ventral view; 9,11 - dorsal view. Scale bars: Figs $8,9-0.25 \mathrm{~mm}$; Figs $10,11-0.2 \mathrm{~mm}$.

Рис. 8-11. Эпигины Poecilochroa cf. senilis $(8,9)$ и Thachyzelotes cumensis $(10,11): 8,10$ — вид снизу; 9, 11 - вид сверху. Масштаб: рис. $8,9-0,25$ мм; рис. 10, $11-0,2$ мм.

they belong to Z. mikhailovi. The species was described from East Kazakhstan Area [Eskov, Marusik, 1995], and then was found in Rostov Area of Russia [Ponomarev, Prishutova, 2017: Zelotes cf. mikhailovi; Ponomarev, 2018]. A new species to the fauna of Astrakhan Area.

Zelotes mundus (Kulczyński, 1897)

MATERIAL. 107, saltmarsh with Bassia sedoides and Tamarix sp., 26.06-3.07.2017.

COMMENTS. A new species to the fauna of Astrakhan Area. In the Lower Volga region, it was recorded from the vicinity of Volgograd [Ponomarev, Khnykin, 2013].

Zelotes segrex (Simon, 1878)

MATERIAL. $10^{7}$, salted dry meadow with camel-thorn (Alhagi pseudalhagi) and Tamarix sp., 27.06-3.07.2017.

\section{LINYPHIIDAE}

Agyneta saaristoi Tanasevitch, 2000

MATERIAL. $10^{7}$, wet forb meadow in willow stands, 29.06 3.07.2017.

COMMENTS. A new species to the fauna of Astrakhan Area. In the Lower Volga region, it was recorded from the vicinity of Volgograd [Ponomarev et al., 2008].

Bathyphantes gracilis (Blackwall, 1841)

MATERIAL. 19, boggy forb-grass meadow, 30.06-3.07.2017.

COMMENTS. A new species to the fauna of Astrakhan Area. Widely distributed in the Holarctic Region [WSC, 2018].
Diplostyla concolor (Wider, 1834)

MATERIAL. 19, boggy forb-grass meadow, 30.06-3.07.2017.

COMMENTS. A new species to the fauna of Astrakhan Area. Widely distributed in the Holarctic Region [WSC, 2018].

Gnathonarium dentatum (Wider, 1834)

MATERIAL. 1ㅇ, dry wormwood-grass meadow, 27.063.07.2017.

COMMENTS. A new species to the fauna of Astrakhan Area. Widely distributed in the Palearctic Region [WSC, 2018].

Microlinyphia impigra (O. Pickard-Cambridge, 1871)

MATERIAL. 1 으, tall grass meadow along willow stands (Salix spp.), 27.06-3.07.2017; 19, willows, 3.07.2017.

COMMENTS. A new species to the fauna of Astrakhan Area. Widely distributed in the Holarctic Region [WSC, 2018].

Neriene clathrata (Sundevall, 1830)

MATERIAL. 19, willows, 3.07.2017.

COMMENTS. A new species to the fauna of Astrakhan Area. Widely distributed in the Holarctic Region [WSC, 2018].

\section{LIOCRANIDAE}

Liocranoeca spasskyi Ponomarev, 2007 Figs 14-16.

Liocranoeca spasskyi Ponomarev, 2007a: 5, f. 2-3 ( $\sigma^{7}+$ ). Liocranoeca spasskyi: Ponomarev, Belosludtsev et Dvadnenko, 2008: 173, f. 11-12 $\left(\sigma^{7}\right)$. 

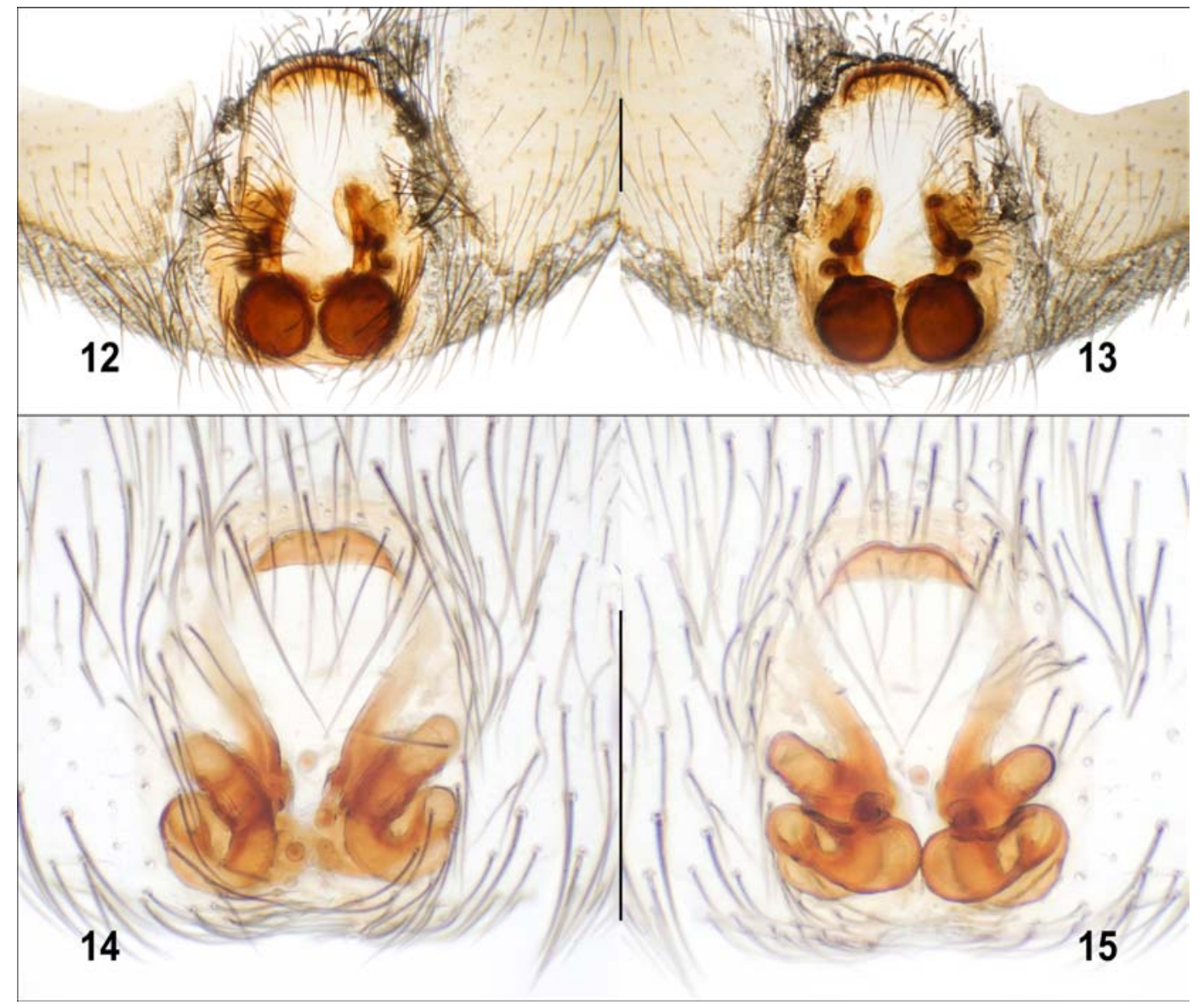

Figs 12-15. Epigynes of Zelotes mikhailovi $(12,13)$ and Liocranoeca spasskyi $(14,15): 12,14$ - ventral view; 13, 15 — dorsal view. Scale bars: $0.25 \mathrm{~mm}$.

Рис. 12-15. Эпигины Zelotes mikhailovi $(12,13)$ и Liocranoeca spasskyi $(14,15): 12,14$ - вид снизу; 13, 15 — вид сверху. Масштаб: 0,25 мм.

MATERIAL. $1 \sigma^{7}$, salted dry meadow with camel-thorn (Alhagi pseudalhagi) and Tamarix sp., 27.06-3.07.2017; 10 $\sigma^{7} \sigma^{7}, 2$, 2 , wet forb meadow in willow stands, 29.06-3.07.2017.

COMMENTS. The species was described from Rostov Area [Ponomarev, 2007a]; in the Caspian lowland, it was recorded from the Bogdo-Baskunchak Nature Reserve [Ponomarev et al., 2008] and northern Dagestan [Ponomarev et al., 2011]. Based on the conformation of copulatory organs (Figs 14-16), this species is very close to L. striata (Kulczyñski, 1881). However, compared to the latter species, $L$. spasskyi is large in size and has a different distributional pattern: viz., it is widespread in the Ponto-Caspian Region, preferring open saline biotopes.

\section{LYCOSIDAE}

Arctosa leopardus (Sundevall, 1832)

MATERIAL. $1+$, saltmarsh with Bassia sedoides and Tamarix sp., 26.06-3.07.2017; 31 $\sigma^{\top} \sigma^{\top}, 7$, 9 , wet forb meadow in willow stands, 29.06-3.07.2017.

Pardosa agrestis (Westring, 1861)

RECORDS. Astrakhan Reserve [Utochkin, 1971].

MATERIAL. $80^{\top} 0^{\top}, 1+$, saltmarsh with Bassia sedoides and Tamarix sp., 26.06-3.07.2017; $70^{7} \sigma^{7}$, 4우, salted dry meadow with camel-thorn (Alhagi pseudalhagi) and Tamarix sp., 27.063.07.2017; $110^{7} 0^{7}, 1$, , wet forb meadow in willow stands, $29.06-$
3.07.2017; 10 $10^{\top}$, 4 우, salted dry meadow with Tamarix sp., 26.063.07.2017; 10 , cordon, meadow, 26.06-3.07.2017.

Pardosa jaikensis Ponomarev, 2007

MATERIAL. $20^{7} 0^{7}, 200$, saltmarsh with Bassia sedoides and Tamarix sp., 26.06-3.07.2017.

COMMENTS. A new species to the fauna of Astrakhan Area. Described from western Kazakhstan [Ponomarev, 2007b], later recorded from northern Dagestan [Ponomarev et al., 2011] and Stavropol Territory [Ponomarev et al., 2017].

Pardosa prativaga (L. Koch, 1870)

MATERIAL. $220^{7} \sigma^{7}, 4$ 우, wet forb meadow in willow stands, 29.06-3.07.2017.

COMMENTS. A new species to the fauna of Astrakhan Area. In the Lower Volga region, it was recorded from the vicinity of Volgograd [Ponomarev, Khnykin, 2013].

Pardosa saltans Töpfer-Hofmann, 2000

MATERIAL. 10", cordon, 26.06-3.07.2017.

COMMENTS. The first record of this species from the northern Caspian region.

Pirata piraticus (Clerck, 1758)

RECORDS. Astrakhan Reserve [Utochkin, 1971; Ponomarev et al., 2008]. 


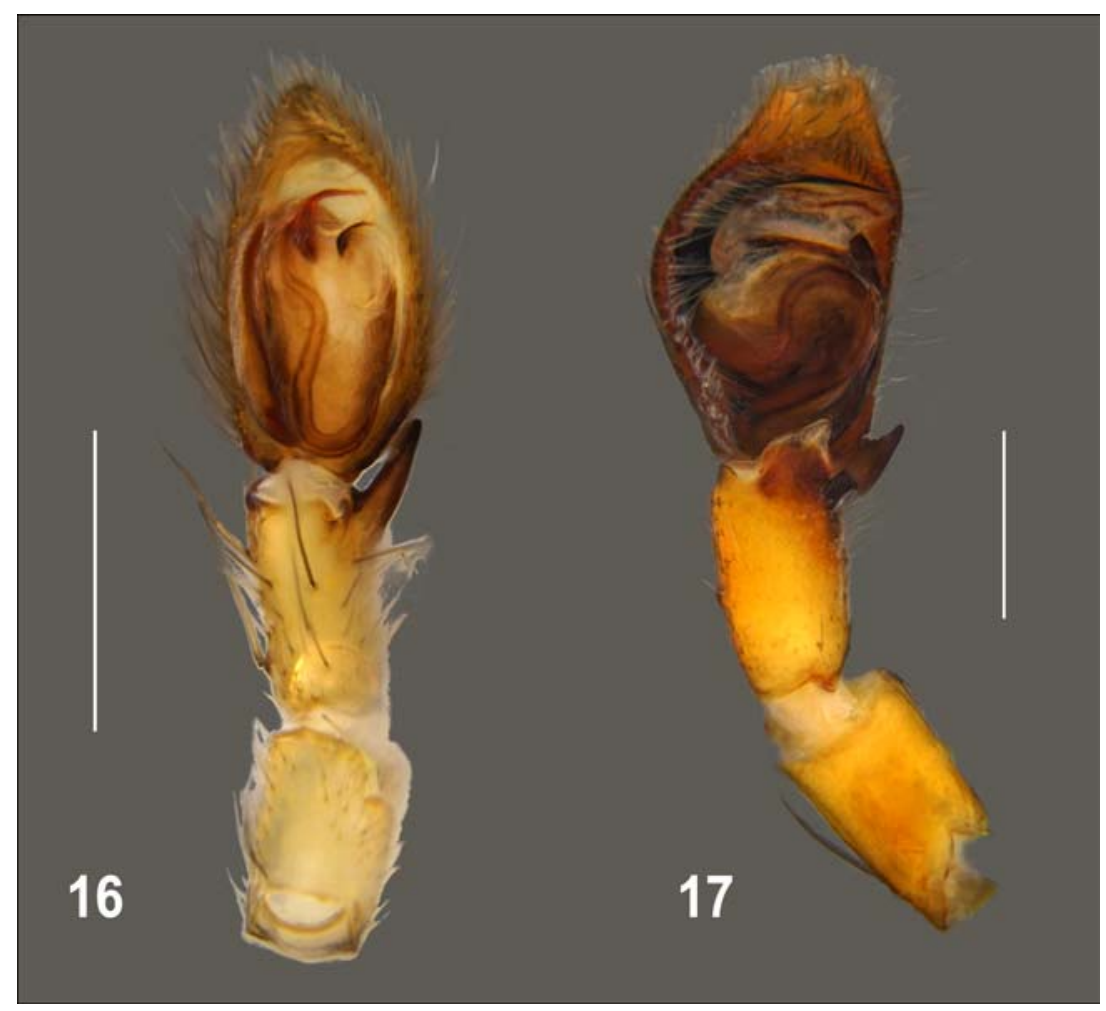

Figs 16-17. Male palps of Liocranoeca spasskyi (16) and Philodromus longipalpis (17), ventral view. Scale bars: $0.5 \mathrm{~mm}$. Рис. 16-17. Пальпы самцов Liocranoeca spasskyi (16) и Philodromus longipalpis (17), вид снизу. Масштаб: 0,5 мм.

MATERIAL. $1 \sigma^{7}$, saltmarsh with Bassia sedoides and Tamarix sp., 26.06-3.07.2017; 10 , 290, boggy meadow with cattail (Typha angustifolia), 29.06.2017; 3 क्ष, wet forb meadow in willow stands, 29.06-3.07.2017; 10', 4웅, reed thicket (Phragmites australis), 3.07.2017.

Piratula latitans (Blackwall, 1841)

MATERIAL. $70^{7} 0^{7}, 1$, , wet forb meadow in willow stands, 29.06-3.07.2017.

COMMENTS. A new species to the fauna of Astrakhan Area. Distributed in Europe [Nentwig et al., 2018].

Trochosa ruricola (De Geer, 1778)

MATERIAL. $10^{7}$, saltmarsh with Bassia sedoides and Tamarix sp., 26.06-3.07.2017; $70^{7} \mathrm{O}^{7}$, 3우, wet forb meadow in willow stands, 29.06-3.07.2017.

Xerolycosa miniata (C.L. Koch, 1834)

RECORDS. Astrakhan Reserve [Ponomarev et al., 2008].

MATERIAL. $1450^{7} \sigma^{7}, 14$ 우, saltmarsh with Bassia sedoides and Tamarix sp., 26.06-3.07.2017; $20^{7} \sigma^{7}$, salted meadow with Tamarix sp., 26.06-3.07.2017.

\section{OXYOPIDAE}

Oxyopes globifer Simon, 1886

MATERIAL. $10^{7}$, saltmarsh with Bassia sedoides and Tamarix sp., 26.06-3.07.2017; 10 , 1\%, salted dry meadow with camelthorn (Alhagi pseudalhagi) and Tamarix sp., 27.06-3.07.2017.

Oxyopes lineatus Latreille, 1806

MATERIAL. $40^{7} \sigma^{7}, 4$, 9 , saltmarsh with Bassia sedoides and Tamarix sp., 26.06-3.07.2017; 107, 2우, dry wormwood-grass

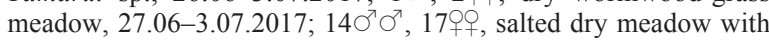

camel-thorn (Alhagi pseudalhagi) and Tamarix sp., 27.063.07.2017; $10^{\text {( }}$, 4 우, tall grass meadow along willow stands (Salix spp.), 27.06-3.07.2017; $30^{7} \sigma^{7}, 4$ 우우, salted forb-grass meadow, 2.07.2017; $10^{7}$, 1 으, forb-grass meadow, 28.06-3.07.2017; $60^{7} \sigma^{7}$, wet forb meadow in willow stands, 29.06-3.07.2017; 13우, boggy forb-grass meadow, 30.06-3.07.2017; 10 3 , 3우, sweeping over Tamarix sp., 26.06-3.07.2017.

\section{PHILODROMIDAE}

Philodromus cespitum (Walckenaer, 1802)

MATERIAL. 1 , , cordon, meadow, 26.06-3.07.2017

\section{Philodromus longipalpis Simon, 1870} Fig. 17.

MATERIAL. 107, cordon, indoor, 26.06-3.07.2017.

COMMENTS. The shape of the tibial apophysis and the bulbus' conformation of the male from the Astrakhan Reserve (Fig. 17) are characteristic of P. longipalpis (cf. Fig. 17 and fig. 10 in Muster \& Thaler [2004]). This species is distributed in southern Europe, Azerbaijan and Iran [WSC, 2018]. In Russia, the species was hitherto recorded from Moscow Area [Pokrovskiy, 1925], the coast of the Taganrog Gulf [Ponomarev, 2011] and the delta of Don River [Ponomarev et al., 2016]. Muster \& Thaler [2004] characterized this species as having a widely Mediterranean (holomediterranean) range. The records of $P$. longipalis from the coast of Azov Sea and the delta of Volga River [Ponomarev, 2011; Ponomarev et al., 2016] do not contradict to this range type. Yet, the findings in Moscow Area [Pokrovskiy, 1925] extend the northern limit of species' range far beyond the Mediterranean region, and, in our opinion, should be considered erroneous. 


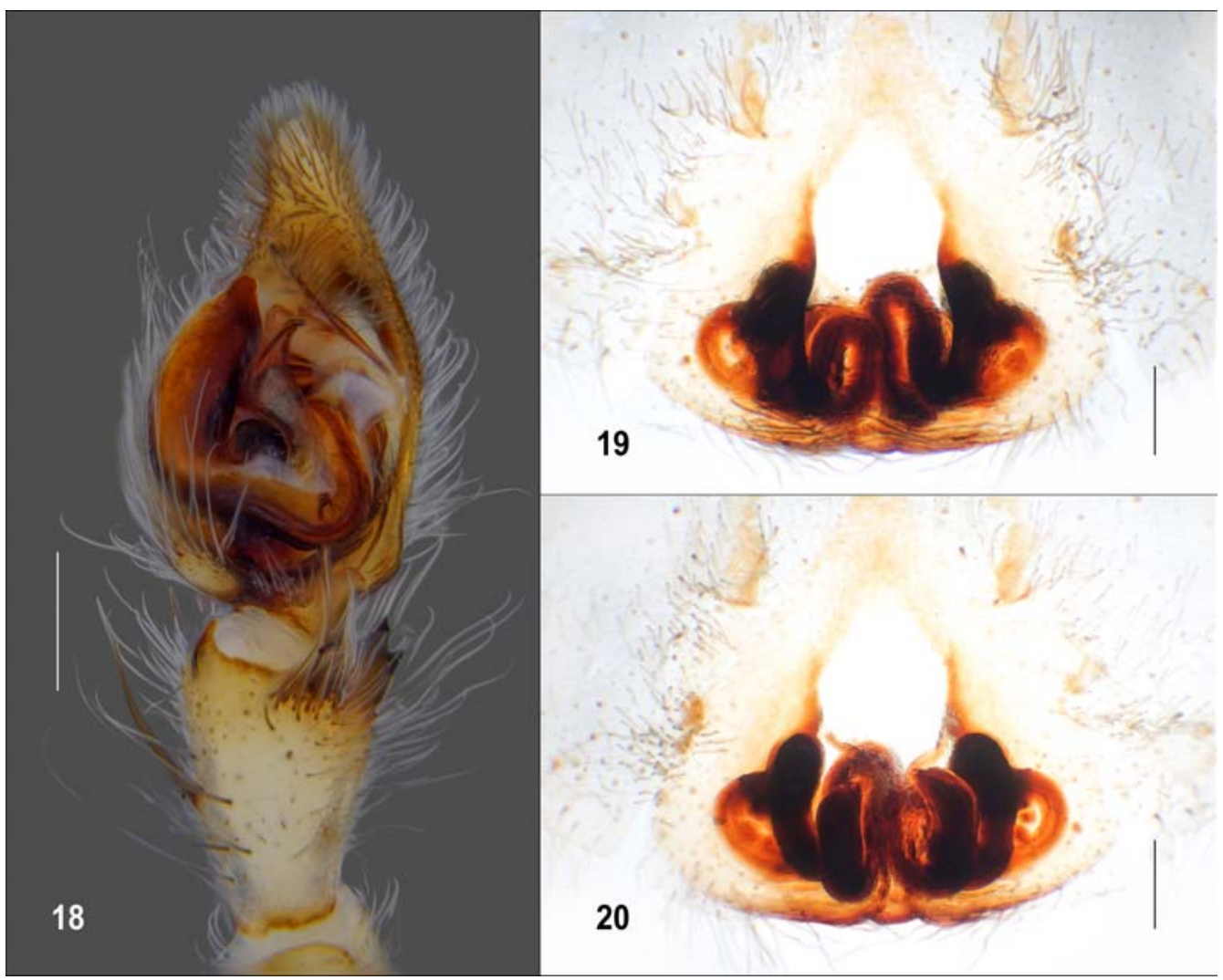

Figs 18-20. Male palp (18) and epigyne $(19,20)$ of Dolomedes plantarius: 18, 19 - ventral view; 20 - dorsal view. Scale bars: fig. $18-0.5 \mathrm{~mm}$; Figs $19,20-0.25 \mathrm{~mm}$.

Рис. 18-20. Пальпа самца (18) и эпигина $(19,20)$ Dolomedes plantarius: 18,19 — вид снизу; 20 - вид сверху. Масштаб: рис. 18 0,5 мм; рис. $19,20-0,25$ мм.

Pulchellodromus ruficapillus (Simon, 1885)

RECORDS. Astrakhan Reserve [Utochkin, 1971: Philodromus glaucinus, misidentification].

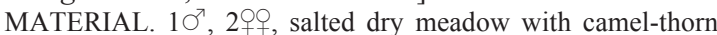
(Alhagi pseudalhagi) and Tamarix sp., 27.06-3.07.2017; $20^{7} 0^{7}$ 5 우, tall grass meadow along willow stands (Salix spp.), 27.063.07.2017; 6오, forb-grass meadow, 28.06-3.07.2017; 3 우, salted forb-grass meadow, 2.07.2017; 2 우, reed thicket (Phragmites australis), 3.07.2017; $10^{7}$, sweeping over Tamarix sp., 26.06-3.07. 2017; $10^{2}$, dry wormwood-grass meadow, 27.06-3.07.2017.

Thanatus oblongiusculus (Lucas, 1846)

MATERIAL. 19, reed-sedge meadow, 28.06.2017.

Thanatus vulgaris Simon, 1870

RECORDS. Astrakhan Reserve [Utochkin, 1971; Ponomarev et al., 2008].

MATERIAL. 10", saltmarsh with Bassia sedoides and Tamarix sp., 26.06-3.07.2017.

Tibellus maritimus (Menge, 1875)

RECORDS. Astrakhan Reserve [Utochkin, 1971; Efimik, 1999; Ponomarev et al., 2008].

MATERIAL. 19, dry wormwood-grass meadow, 27.063.07.2017

Tibellus oblongus (Walckenaer, 1802)

RECORDS. Astrakhan Reserve [Utochkin, 1971; Efimik, 1999; Ponomarev et al., 2008].
MATERIAL. 10 $10^{7}, 1$, saltmarsh with Bassia sedoides and Tamarix sp., 26.06-3.07.2017; $10^{7}$, dry wormwood-grass meadow, 27.06-3.07.2017; $10^{7}, 290$, salted dry meadow with camel-thorn (Alhagi pseudalhagi) and Tamarix sp., 27.06-3.07.2017; $30^{7} \sigma^{7}$, 4우, reed-sedge meadow, 28.06.2017.

PHOLCIDAE

Pholcus ponticus Thorell, 1875

RECORDS. Astrakhan Reserve [Ponomarev et al., 2008].

MATERIAL. 10", cordon, indoor, 26.06-3.07.2017.

\section{PISAURIDAE}

Dolomedes plantarius (Clerck, 1758)

Figs 18-20.

Dolomedes plantarius: Lecigne, 2016: 32, f. 5-10 ( (

RECORDS. Astrakhan Reserve [Utochkin, 1971].

MATERIAL. $20^{7} \sigma^{7}$, wet forb meadow in willow stands, 29.063.07.2017; 107, 2우, reed thicket (Phragmites australis), 29.063.07.2017.

COMMENTS. In Europe, this species is considered rare [Nentwig et al., 2018] and even endangered. For example, in Belarus D. plantarius is included in the Red Book [Ivanov et al., 2017]. The conformation of copulatory organs of the studied specimens (Figs 18-20) are evidence that they indeed belong to $D$. plantarius. The data by Utochkin [1971] and our material (during a short period of fieldwork five mature individuals were collected) support the idea that in the Astrakhan Reserve D. plantarius is not a rare species. 
Pisaura mirabilis (Clerck, 1758)

MATERIAL. 3 우, tall grass meadow along willow stands (Salix spp.), 27.06-3.07.2017; 1ㅇ, forb-grass meadow, 28.06-3.07.2017.

\section{SALTICIDAE}

Asianellus festivus (C.L. Koch, 1834)

MATERIAL. 107, saltmarsh with Bassia sedoides and Tamarix sp., 26.06-3.07.2017.

COMMENTS. A new species to the fauna of Astrakhan Area. In the Lower Volga region, it was recorded from Volgograd Area [Logunov, Marusik, 2000].

Attulus distinguendus (Simon, 1868)

MATERIAL. $20^{7} \sigma^{7}$, saltmarsh with Bassia sedoides and Tamarix sp., 26.06-3.07.2017.

COMMENTS. A new species to the fauna of Astrakhan Area. In the Lower Volga region, it was recorded from Volgograd Area [Simon, 1878].

Ballus chalybeius (Walckenaer, 1802)

MATERIAL. 19, boggy forb-grass meadow, 30.06-3.07.2017.

Euophrys frontalis (Walckenaer, 1802)

MATERIAL. 1으, cordon, meadow, 26.06-3.07.2017.

COMMENTS. A new species to the fauna of Astrakhan Area. Widely distributed in the Palearctic Region [WSC, 2018].

\section{Heliophanus auratus C.L. Koch, 1835}

RECORDS. Astrakhan Reserve [Ponomarev et al., 2008]. MATERIAL. 1 , , saltmarsh with Bassia sedoides and Tamarix sp., 26.06-3.07.2017; 19, reed-sedge meadow, 28.06.2017; $10^{7}$, forb-grass meadow, 28.06-3.07.2017; 1ㅇ, reed thicket (Phragmites australis), 3.07.2017.

Logunyllus vittatus (Thorell, 1875)

MATERIAL. 19, reed-sedge meadow, 28.06.2017.

Pellenes brevis (Simon, 1868)

MATERIAL. 10", saltmarsh with Bassia sedoides and Tamarix sp., 26.06-3.07.2017.

COMMENTS. A new species to the fauna of Astrakhan Area. Distributed in southern Europe [Nentwig et al., 2018].

SPARASSIDAE

Micrommata virescens (Clerck, 1758)

RECORDS. Astrakhan Reserve [Utochkin, 1971].

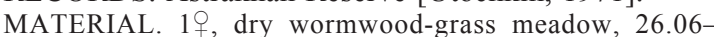
3.07.2017

\section{TETRAGNATHIDAE}

Pachygnatha clercki Sundevall, 1823

RECORDS. Astrakhan Reserve [Utochkin, 1971].

MATERIAL. $10^{7}$, wet forb meadow in willow stands, 29.063.07.2017; $10^{\top}$, salted forb-grass meadow, 2.07.2017.

Pachygnatha degeeri Sundevall, 1830

RECORDS. Astrakhan Reserve [Ponomarev et al., 2008].

MATERIAL. $10^{7}, 1$, , wet forb meadow in willow stands, 29.06-3.07.2017.

\section{Tetragnatha dearmata Thorell, 1873}

RECORDS. Astrakhan Reserve [Ponomarev et al., 2008].

MATERIAL. 1 , t tall grass meadow along willow stands (Salix spp.), 27.06-3.07.2017; 19, reed thicket (Phragmites australis), 3.07.2017; 19, sweeping over Tamarix sp., 26.06-3.07.2017.
Tetragnatha montana Simon, 1874

RECORDS. Astrakhan Reserve [Utochkin, 1971: Tetragnatha solandri; Ponomarev et al., 2008].

MATERIAL. $10^{7}, 5$ 우, reed thicket (Phragmites australis), 3.07.2017.

Tetragnatha nigrita Lendl, 1886

MATERIAL. 19, reed thicket (Phragmites australis), 3.07.2017.

Tetragnatha shoshone Levi, 1981

RECORDS. Astrakhan Reserve [Sozontov, Esyunin, 2015: Tetragnatha qiuae].

MATERIAL. $10^{7}$, 1 우, willows, $3.07 .2017 ; 10^{7}$, reed thicket (Phragmites australis), 3.07.2017.

Tetragnatha striata L. Koch, 1862

RECORDS. Astrakhan Reserve [Utochkin, 1971: Eugnatha striata; Ponomarev et al., 2008].

MATERIAL. $30^{7} \sigma^{7}, 2$ 우, thicket of cattail (Typha angustifolia), 29.06.2017; $30^{\top} \sigma^{\top}, 2$, + , , reed thicket (Phragmites australis), 3.07.2017.

\section{THERIDIIDAE}

Enoplognatha mordax (Thorell, 1875)

MATERIAL. 19, meadow with reed, 3.07.2017.

Kochiura aulica (C.L. Koch, 1838)

MATERIAL. 1 우, salted dry meadow with camel-thorn (Alhagi pseudalhagi) and Tamarix sp., 27.06-3.07.2017.

COMMENTS. A new species to the fauna of Astrakhan Area. Distributed in southern Europe [Nentwig et al., 2018].

Latrodectus tredecimguttatus (P. Rossi, 1790)

MATERIAL. 10, cordon, on a building, 26.06-3.07.2017.

Parasteatoda tepidariorum (C.L. Koch, 1841)

MATERIAL. 1 , t tall grass meadow along willow stands (Salix spp.), 27.06-3.07.2017; 3우, cordon, indoor, 26.06-3.07.2017.

Steatoda castanea (Clerck, 1758)

RECORDS. Astrakhan Reserve [Utochkin, 1971: Teutana castanea].

MATERIAL. 3 99 , cordon, on a building, 26.06-3.07.2017.

\section{THOMISIDAE}

Ebrechtella tricuspidata (Fabricius, 1775)

RECORDS. Astrakhan Reserve [Utochkin, 1971: Misumemops tricuspidatus].

MATERIAL. $10^{\top}$, 19, dry wormwood-grass meadow, 27.063.07.2017; 1 우, willows, $3.07 .2017 ; 10^{7}$, cordon, meadow, 26.063.07.2017.

\section{Heriaeus sp.}

Figs 21-23.

MATERIAL. $10^{7}$, tall grass meadow along willow stands (Salix spp.), 27.06-3.07.2017; 107, forb-grass meadow, 28.06-3.07.2017.

COMMENTS. Based on the conformation of copulatory organs of the studied males (Figs 21-22), they are very close to $H$. graminicola. However, peculiarities of their coloration (Fig. 23) do not allow us to identify these specimens as $H$. graminicola with certainty. It is likely that the males belong to $H$. delticus Utotschkin, 1985 described and known to date from a single female from the Astrakhan Reserve [Utochkin, 1985]. 


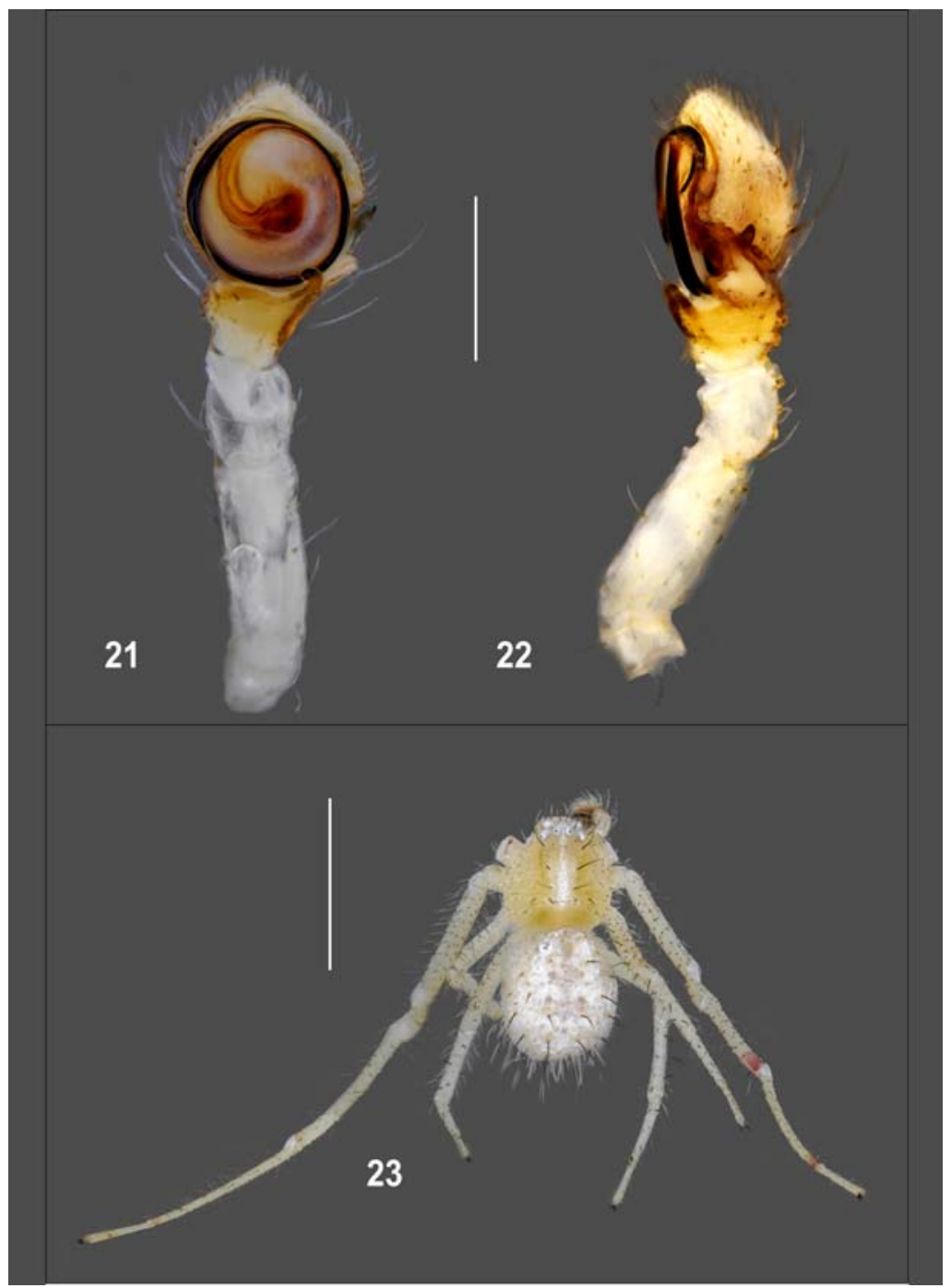

Figs 21-23. Male palp $(21,22)$ and male habitus (23) of Heriaeus sp.: 21 - ventral view; 22 -lateral view; 23 - dorsal view. Scale bars: Figs $21,22-0.5 \mathrm{~mm}$; fig. $23-2.5 \mathrm{~mm}$.

Рис. 21-23. Пальпа $(21,22)$ и внешний вид (23) самца Heriaeus sp.: 21 - вид снизу; 22 - вид сбоку; 23 - вид сверху. Масштаб: рис. $21,22-0,5$ мм; рис. $23-2,5$ мм.

Ozyptila praticola (C.L. Koch, 1837)

RECORDS. Astrakhan Reserve [Utochkin, 1971].

MATERIAL. $80^{7} \sigma^{7}, 1$, , wet forb meadow in willow stands, 29.06-3.07.2017.

Ozyptila simplex (O. Pickard-Cambridge, 1862)

MATERIAL. $10^{7}$, reed-sedge meadow, 28.06.2017; $20^{7} \sigma^{7}$, wet forb meadow in willow stands, 29.06-3.07.2017.

\section{Runcinia grammica (C.L. Koch, 1837)}

RECORDS. Astrakhan Reserve [Utochkin, 1971: Runcinia lateralis].

MATERIAL. 107, 290, saltmarsh with Bassia sedoides and Tamarix sp., 26.06-3.07.2017; $20^{7} \sigma^{7}$, dry wormwood-grass meadow, 27.06-3.07.2017; $10^{7}$, salted dry meadow with camel-thorn (Alhagi pseudalhagi) and Tamarix sp., 27.06-3.07.2017; 30 $0^{7}$, 3 우, tall grass meadow along willow stands (Salix spp.), 27.063.07.2017; 4우, reed-sedge meadow, 28.06.2017; 1우, forb-grass meadow, 28.06-3.07.2017; 10, 1 우 , salted forb-grass meadow, 2 . 07.2017 .
Thomisus onustus Walckenaer, 1805

RECORDS. Astrakhan Reserve [Utochkin, 1971: Thomisus albus].

MATERIAL. 10 $0^{7}$, saltmarsh with Bassia sedoides and Tamarix sp., 26.06-3.07.2017; 20+9, salted dry meadow with camelthorn (Alhagi pseudalhagi) and Tamarix sp., 27.06-3.07.2017; $10^{7}$, tall grass meadow along willow stands (Salix spp.), 27.063.07.2017; $10^{7}$, forb-grass meadow, 28.06-3.07.2017; $10^{7}$, boggy forb-grass meadow, 30.06-3.07.2017; $10^{7}$, salted forb-grass meadow, 2.07.2017.

Xysticus laetus Thorell, 1875

MATERIAL. 1 웅, salted dry meadow with camel-thorn (Alhagi pseudalhagi) and Tamarix sp., 27.06-3.07.2017; 1 , forb-grass meadow, 28.06-3.07.2017.

COMMENTS A new species to the fauna of Astrakhan Area. Distributed in southern Europe [Nentwig et al., 2018].

Xysticus mongolicus Schenkel, 1963

MATERIAL. 19, salted dry meadow with camel-thorn (Alhagi pseudalhagi) and Tamarix sp., 27.06-3.07.2017. 
COMMENTS. A new species to the fauna of Astrakhan Area. In the Lower Volga region, it was recorded from Volgograd Area [Ponomarev, Khnykin, 2013].

Xysticus ulmi (Hahn, 1831)

RECORDS. Astrakhan Reserve [Utochkin, 1971].

MATERIAL. $1+$, tall grass meadow along willow stands (Salix spp.), 27.06-3.07.2017.

\section{TITANOECIDAE}

Titanoeca turkmenia Wunderlich, 1995

MATERIAL. 19 , saltmarsh with Bassia sedoides and Tamarix sp., 26.06-3.07.2017; $10^{7}$, salted dry meadow with camel-thorn (Alhagi pseudalhagi) and Tamarix sp., 27.06-3.07.2017; 10 , salted meadow with Tamarix sp., 26.06-3.07.2017.

COMMENTS. A new species to the fauna of Astrakhan Area. Described from Turkmenia [Wunderlich, 1995], it was recorded from the north-western part of Caspian lowland [Ponomarev et al., 2011].

A short-term field study of spider fauna which were conducted at the Damchik site of the Astrakhan Nature Reserve has yielded 89 species in 17 families, 30 species are new to the fauna of Astrakhan Area, 57 species are first found in the Astrakhan Reserve, three species remain undetermined or determined provisionally: Haplodrassus sp., Poecilochroa cf. senilis, Heriaeus sp.

Thus, based both on the original and literaturederived data, to date 124 species of spiders in 19 families have been known from the territory of the Astrakhan Reserve.

ACKNOWLEDGEMENTS. The work of A.V. Ponomarev and V.Yu. Shmatko made in the framework of the State task of the SSC RAS in 2018, state registration of the project No. 01201363191.

\section{References}

Astrakhanskiy zapovednik [Astrakhan Reserve]. 1991. / Krivonosov G.A., Rusakov G.V. (eds.). Moscow: Agropromizdat. 190 p. [In Russian]

Chatzaki M., Russell-Smith A. 2017. New species and new records of ground spiders (Araneae: Gnaphosidae) from Cyprus // Zootaxa. Vol.4329. No.3. P.237-255.

Efimik V.E. 1999. A review of the spider genus Tibellus Simon, 1875 of the East Palaearctis (Aranei: Philodromidae) // Arthropoda Selecta. Vol.8. No.2. P.103-124.

Eskov K.Yu., Marusik Yu.M. 1995. On the spider from Saur Mt. range, Eastern Kazakhstan (Arachnida: Araneae) // Beiträge zur Araneologie. Bd.4 (für 1994). P.55-94.

Ivanov V., Prishepchik O., Setrakova E. 2017. Dolomedes plantarius (Araneae, Pisauridae) in Belarus: records, distribution and implications for conservation // Arachnol. Mitt. H.54. P.33-37.

Kovblyuk M.M., Nadolny A.A. 2008. The spider genus Micaria Westring, 1851 in the Crimea (Aranei: Gnaphosidae) // Arthropoda Selecta. Vol.16. No.4. P.215-236.

Kovblyuk M.M., Tuneva T.K. 2008. Three interesting species of Gnaphosidae from Crimea (Arachnida: Aranei) // Arthropoda Selecta. Vol.17. No.3-4. P.157-164.

Lecigne S. 2016. Redécouverte de Dolomedes plantarius (Clerck, 1758) (Araneae, Pisauridae) en région Nord - Pas-de-Calais (France), actualisation de sa distribution en France et aperçu de la situation en Europe // Revue Arachnologique. Sér.2. No.3. P.28-41.

Levy G. 1998. The ground-spider genera Setaphis, Trachyzelotes, Zelotes, and Drassyllus (Araneae: Gnaphosidae) in Israel // Israel Journal of Zoology. Vol.44. P.93-158.
Logunov D.V., Marusik Yu.V. 2000. Miscellaneous notes on Palaearctic Salticidae (Arachnida: Aranei) // Arthropoda Selecta. Vol.8 (for 1999). No.4. P.263-292.

Marusik Yu.V., Fomitchev A.A., Omelko M.M. 2014. A survey of East Palaearctic Gnaphosidae (Araneae). 1. On the Berlandina Dalmas, 1992 (Gnaphosidae) from Mongolia and adjacent regions // Zootaxa. Vol.3827. No.2. P.187-213.

Mikhailov K.G. 2013. The spiders (Arachnida: Aranei) of Russian and adjacent countries: a nonannotated checklist. Arthropoda Selecta. Supplement No.3. Moscow: KMK Scientific Press Ltd. 262 p.

Muster C., Thaler K. 2004. New species and records of Mediterranean Philodromidae (Arachnida, Araneae): I. Philodromus aureolus group // Thaler K. (Hrsg.). Diversität und Biologie von Webspinnen, Skorpionen und anderen Spinnentieren. Denisia. Bd.12. S.305-326.

Nentwig W., Blick T., Gloor D., Hänggi A., Kropf C. 2018. Spinnen Europas. Online at http://www.araneae.unibe.ch Version 05.2018. doi: 10.24436/1.

Pickard-Cambridge O. 1872. General list of the spiders of Palestine and Syria, with descriptions of numerous new species, and characters of two new genera // Proceedings of the Zoological Society of London. Vol.40. No.1. P.212-354, Pl. XIII-XVI.

Pokrovskiy S.V. 1925. [Spider fauna of the Kleazma River Basin] / / Zapiski biostantsii v Bolsheve. No.1. P.19-25 [in Russian].

Polchaninova N.Yu., Prokopenko E.V. 2013. Catalogue of the spiders (Arachnida, Aranei) of Left-Bank Ukraine. Arthropoda Selecta. Supplement No. 2. Moscow: KMK Scientific Press Ltd. 268 p.

Ponomarev A.V. 1979. [New species of spiders of the family Gnaphosidae from northem Ciscaspia] // Zoologicheskii zhurnal. Vol.58. No.6. P.921-923 [in Russian].

Ponomarev A.V. 1981. [To the fauna and ecology of spiders of the family Gnaphosidae (Aranei) of the semidesert zone of European part of the USSR] // Fauna i ekologiya nasekomych [Fauna and ecology of Insects]. Perm: Perm University Publ. P.54-68 [in Russian].

Ponomarev A.V. 2007a. [New spiders (Aranei) from the south-east of Europe] // Caucasian Entomological Bulletin. Vol.3. No.1. P.3-7 [in Russian]

Ponomarev A.V. 2007b. [New taxa of spiders (Aranei) from the south of Russia and Western Kasakhstan] // Caucasian Entomological Bulletin. Vol.3. No.2. P.87-95 [in Russian].

Ponomarev A.V. 2008. [The additional data to the spider fauna (Aranei) of the south-east of Russian Plain] // Vestnik yuzhnogo nauchnogo tsentra. Vol.4. No.3. P.78-86 [in Russian].

Ponomarev A.V. 2011. [Spiders (Aranei) in territories adjacent to the Northern and Southern borders of the Lower Don] // Tsimlyanskoe vodokhranilishche: sostoyanie vodnykh $i$ pribrezhnykh ekosistem, problemy $i$ puti resheniya. Rostov-on-Don: Southern Scientific Centre of the Russian Academy of Sciences Publishers. P.120-154 [in Russian].

Ponomarev A.V. 2017. [Spiders (Arachnida: Aranei) of steppe and meadow-steppe habitats of gully and ravine ecosystems of the valley of the Don River lower reaches] // Trudy Russkogo Entomol. Obshchestva. St. Petersburg. Vol.88. No.1. P.118131 [in Russian].

Ponomarev A.V. 2018. [A new species of spiders of the genus Zelotes Gistel, 1848 (Aranei: Gnaphosidae) from the NorthEast Pre-Caspian region] // Caucasian Entomological Bulletin. Vol.14. No.1. P.3-5 [in Russian].

Ponomarev A.V., Abdurakhmanov G.M. 2014. [Spiders (Aranei) of North Caspian coast and islands] // Yugh Rossii: ekologiya, razvitie. No.1. P.76-121 [in Russian].

Ponomarev A.V., Abdurakhmanov G.M., Alieva S.V., Dvadnenko K.V. 2011. [Spiders (Arachnida: Aranei) of the costal and island territories of northern Dagestan] // Yugh Rossii: ekologiya, razvitie. No.4. P.126-143 [in Russian].

Ponomarev A.V., Alekseev S.K., Kozminykh V.O., Shmatko V.Yu. 2017. Spiders (Arachnida: Aranei) of Stavropol Province, Russia // Arthropoda Selecta. Vol.26. No.2. P.155-173.

Ponomarev A.V., Belosludtsev E.A., Dvadnenko K.V. 2008. [Spiders (Aranei) of the Lower Volga Region (Astrakhan and Vol- 
gograd areas of Russia) with the description of new taxa] Caucasian Entomological Bulletin. Vol.4. No.2. P.163-185 [in Russian].

Ponomarev A.V., Dvadnenko K.V. 2012. [Notes on taxonomy and fauna of spiders (Aranei) of the south of Russia and Western Kazakhstan] // Yug Rossii: ekologiya, razvitie. No.4. P.42-53 [in Russian].

Ponomarev A.V., Khnykin A.S. 2013. [Spiders (Aranei) of Volgograd city and its environs] // Yugh Rossii: ekologiya, razvitie. No.4. P.109-136 [in Russian].

Ponomarev A.V., Prishutova Z.G. 2017. [Terrestrial spiders (Aranei) of Vodnyi Island (Manych-Gudilo Lake)] // Nauka Yuga Rossii. Vol.13. No.2. P.60-65 [in Russian].

Ponomarev A.V., Prokopenko E.V., Ivliev P.P., Shmatko V.Yu. 2016. [Spiders (Aranei) of the coast of Taganrog Bay (the Sea of Azov) and the Don River delta] // Caucasian Entomological Bulletin. Vol.12. No.1. P.3-28 [in Russian].

Ponomarev A.V., Tsvetkov A.S. 2004. [The generalized data on spiders (Aranei) of the Nature Reserve "Rostovskiy"] // Trudy Gosudarstvennogo prirodnogo zapovednika "Rostovskiy" [Proceedings of the State Nature Reserve "Rostovskiy"]. Iss. 3. Rostov-on-Don: Donskoy Izdatelskiy Dom. P.84-104 [in Russian].

Ponomarev A.V., Tsvetkov A.S. 2006. [New and rare spiders of family Gnaphosidae (Aranei) from a southeast of Europe] // Caucasian Entomological Bulletin. Vol.2. No.1. P.5-13 [in Russian].
Simon E. 1878. Liste des espèces européennes et algériènnes de la famille des Attidae, composant la collection de M. le comte E. Keyserling. Études arachnol. 8e Mém. No.14 // Ann. Soc. Entomol. Fr. Sér.5. T.8. 1er Partie. P.201-212.

Sozontov A.N., Esyunin S.L. 2015. [Taxonomical remarks about two spider species from the genus Tetragnatha Latreille 1804 (Aranei, Tetragnathidae)] // Zoologicheskiy zhurnal. Vol.94. No.3. P.311-319 [in Russian].

Thorell T. 1875. Verzeichniss Südrussischer Spinnen // Horae Soc. Ent. Ross. T.11. P.39-122.

Utochkin A.S. 1971. [To the spider fauna of the Astrakhan Reserve] // Voprosy arahknoentomologii. Uchenye zapiski Permskogo universiteta. No.249. P.154-157 [in Russian].

Utochkin A.S. 1985. [Materials to the spider fauna of the genus Heriaeus (Aranei, Thomisidae) of USSR] // Fauna i ekologiya paukov SSSR. Trudy Zoologicheskogo Instituta. Leningrad. Vol.139. P.105-113 [in Russian].

World Spider Catalog. 2018. World Spider Catalog. Natural History Museum Bern, online at http://wsc.nmbe.ch, version 19.0, accessed on 6.05.2018. doi: 10.24436/2.

Wunderlich J. 1995. Revision der Titanoeca tristis-gruppe, mit zwei Neubeschreibungen aus der Westlichen Paläarktis (Arachnida: Araneae: Titanoecidae) // Beiträge zur Araneologie. Bd.4 (für 1994). P.731-738.

Responsible editor D.V. Logunov 